УДК 811.162 .2

Dergach D.V.

\title{
STYLISTIC RESOURCE OF CREOLIZATION IN MODERN MASS-MEDIA
}

Abstract. The author analyzes stylistic resource and potential of creolization in modern mass media. Approaches to the scientific interpretation of the phenomenon in the paradigm of communicative linguistics, functional stylistics are considered. The intra- and extralinguistic factors that actualize the means of creolization in modern media-media communication are taken into consideration.

The author proposes to interpret partial and associative types of media creolization, which determine the dominant verbal / nonverbal components in media texts. The functional potential of means of creolization of the media language, aimed at informing, analyzing and influencing the language consciousness of the mass audience is also determined.

Key words: creolization, mass media style, stylistic resource, semantic field.

Information about author: Dergach Dmytro Valerijovych - PhD, associate professor; associate professor of the department of stylistics and language communication; Institute of philology; Kyiv national Taras Shevchenko university.

E-mail: dimyla_philolog@ukr.net.

Дергач Д.В.

\section{СТИЛІСТИЧНИЙ РЕСУРС КРЕОЛІЗАЦЇ̈ В СУЧАСНИХ МАС-МЕДІА}

Анотація. У статті аналізується стилістичний ресурс креолізації в сучасних мас-медіа. Розглядаються підходи до фахової 
Актуальні проблеми української лінгвістики: теорія і практика

інтерпретації явищуа в парадигмі комунікативної лінгвістики, функціональної стилістики. Беруться до уваги інтра- й екстралінгвальні фактори, щуо актуалізують засоби креолізації в сучасній мас-медійній комунікації. Розрізняються часткова та асочіативна креолізації, щзо визначають домінанту вербальних / невербальних компонентів у медіатекстах. Визначається функціональний потенціал засобів креолізації мови модерних ЗМI, орієнтованої на інформування, аналітику та вплив на мовну свідомість масової аудиторії.

Ключові слова: креолізачія, стиль масової інформацїі, стилістичний ресурс, смислове навантаження.

Інформація про автора: Дергач Дмитро Валерійович кандидат філологічних наук, доцент; доцент кафедри стилістики та мовної комунікацї; Інститут філологї; Київський національний університет імені Тараса Шевченка.

Електронна адреса: dimyla_philolog@ukr.net.

Дергач Д.В.

\section{СТИЛИСТИЧЕСКИЙ РЕСУРС КРЕОЛИЗАЦИИ В СОВРЕМЕННЫХ МАСС-МЕДИА}

Аннотация. B статье анализируется стилистический ресурс креолизации в современных масс-медиа. Рассматриваются подходы $к$ научной интерпретации явления в парадигме коммуникативной лингвистики, функцииональной стилистики. Принимаются во внимание интра- и экстралингвистические факторы, актуализирующие средства креолизации в современной масс-медийной коммуникации. Различаются частичная и ассоциативная креолизации, которые определяют доминанту вербальных / невербальных компонентов в медиатекстах. Определяется функичиональный потенциал средств креолизацчи языка современных СМИ, ориентированного на информирование, аналитику и влияние на языковое сознание массовой аудитории. 
Ключевые слова: креолизаиия, стиль массовой информации, стилистический ресурс, смысловая нагрузка.

Информация об авторе: Дергач Дмитрий Валерьевич кандидат филологических наук, доцент; дочент кафедры стилистики и языковой коммуникаиии; Институт филологии; Киевский национальный университет имени Тараса Шевченко.

Электронный адрес: dimyla_philolog@ukr.net.

The creolization of media communication nowadays actualizes the dynamic functional resource of modern mass media, oriented not only on informing and analyzing but also on the influence, formation and verbalization of mass language consciousness.

The investigation of creolization correlates with the aspects of communicative and functional linguistics, actualized in the science in the 20th century. These trends intertwine the text not as a resource of communication, verbal / non-verbal interaction between speakers. That is why, the aspectology of the interpretation of the sign system of language is deepened in the context of its dependence on the units of other sign systems, that in general makes the base for the understanding of creolization process.

The concept of creolization was formulated and systematically interpreted at the end of the 20th century. According to the researchers, "the texture of creolized texts consists of two non-homogeneous parts (verbal language (speech) and non-verbal (belonging to other sign systems, than language)" [7, p. 180-181]. In general, in science, there are other, alternative interpretation of the analyzed phenomenon, but they take into account the original vision of the authors of this term $-\mathrm{Y}$. Sorokin and Y. Tarasov, giving only shades in its semantic field:

1) creolization is realized in "a special linguistic-visual phenomenon, a text in which verbal and non-verbal components 
form one visual, structural, semantic and functional unit, providing its complex pragmatic effect on the addressee" [1, p. 71];

2) "creolized text is a complex unit, in which verbal and non-verbal elements form one visual, structural, semantic and functional integer, aimed at the complex impact on the addressee" [3, p. 43];

3) creolization is a "combination of elements of various semiotic systems, that depends on the target setting of the author of the text" [5, p. 60]

4) creolized text - "complex text formation, that includes, in addition to the units of the natural language, signs of other semioticsystems (image, animation, music, light accompaniment etc.). At the same time components of creolized texts form a single unit both visually and functionally "[6];

5) creolization is a functional resource of "paralinguistically active text ... in the coding of which a combination of a natural language with elements of other, non-verbal semiotic systems is used" [8, p. 98].

In general, in the functional styles of the literary language the resource of creolization is characterized by a functional role, primarily of non-verbal components. In particular, circuits, tables, graphs, diagrams, formulas (that also refer to units of text creolization) are used in scientific, official styles for the purpose of revealing, visual confirmation of the communication, and in the media - the functions in the informational and analytical genres of the article, reporting, discussions, news, etc. are supplemented by the possible influence, persuasion of the recipients in the content of information, actualization of certain meanings of which is an important means of manipulating the language consciousness of the audience. Among creolizing means we can also interpret a font (with different spelling effects), underscore, color selection, etc., that means, firstly, the activation of the attention of the recipient as the initial stage of perception of information. And its 
meaning, lingual nature, audiovisual support in this case are actualized at the next stages of cognitive processes.

The question of stratification of the phenomenon of creolization in the media sphere has a mixed solution. It depends on the variability of the classification criteria based on the distinction.

According to the specificity of verbal and non-verbal components of media communication, we can analyze texts with full and partial creolization. Full creolization involves the lack of language units in the text, that has only graphic tools, whose semantic field fully implements the communicative intention of the speaker, the author of the message. Information in such texts has a precedent character (for history, culture of society), or is connected with current events of the present day, and therefore it is recognizable, can be encrypted only graphically. Often, such way of transmitting information is used in various types of advertising, on billboards, is implemented in Internet communication - in the functional paradigm of cartoons, sketches, etc. In this case, the author deliberately does not use the language, giving the image of the characteristics of a full-fledged media text. Unlike a similar situation with the creation and functioning of artistic text, when it comes from one side to the author, and on the other - from an illustrator who has graphically (precisely, in meaning) to convey the plot of the text, the character of the heroes, etc. The media communication is more free and varied in terms of interpreting events, phenomena, individuals, because media is analyzed through the specifics of its representation to the mass audience.

Partial creolization, in turn, combines verbal and non-verbal components of communication, which extends the means of decoding transmitted meanings. Such texts, of course, are more frequent and functionally diverse. They are not rigidly determined by the background knowledge of the recipients, and therefore 
appeal to various facts of social life. In the architectonics of partially creolized texts links, explanations, notes and other additional elements can be used to clarify the content of the transmitted information, that generally points the main characteristics of media communication - speed, accessibility, comprehension, etc.

For a better understanding and systematic analysis of the media's creolizing resource, it is also necessary, in our opinion, to pay attention to its semantic expressions: it is a question of the implicit or explicit nature of the commensurability of codes in media communication. Thus, direct creolization is based on the equivalence of information and non-verbal media components that accompany it in the communication. It is often observed at pressconferences, speeches, articles, and rarely in advertising, when graphic elements (emblems, photos, figures, diagrams, etc.) completely duplicate the text. In this case, we can speak about equivalent nature of visualization and verbalization of thought.

The resource of associative creolization involves the usage of paralinguistic means that are semantically associated with the information transmitted in the media. Often it is associated with established cultural parallels, paternalistic components of communication, that have a unified character, because they are associated with certain traditions, repetitive actions, reactions, etc. For example, a Christmas tree - for Christmas, Santa Claus for New Year, Easter eggs, Easter - for Easter, sea, entertainment - mostly in the summer season. Although today we can see the integration of symbolized elements, when, in particular in the advertisement of winter, festive "hot" tours you can see a Christmas tree on the beach or Snow maiden by the pool. Such an oxymoronarity, a paradox of meanings, and their combination in the information in the media sphere are evidenced by the openness, mobility of all without exception means of creating and extending of information to the mass recipient. 
On the other hand, associative creolization is also associated with the functional implementation of the plans of the author of the media text to reinforce verbalized thoughts with additional means - in order to enhance, perpetuate the cognitive, attractive effect of information. Such variation can be based on the usage of specially created or well-known objects of audiovisual art, not marked by cultural associations. Or vice versa - we can pay attention on the intertextual creolization, that involves the inclusion of units that have a culturally specific character as nonverbal components of media communication, and therefore are recognizable and implement a well-defined, well-defined semantic, emotional resource.

In the genres of media communication in connection with their functional paradigm, the usage of creolising components has an inconsistent character - from complete absence to predominance in the architectonics of the text. For example, newsprint genres are less skewed. Journal publications, in turn, are more determined by the variability of information transmission, but are still limited by the usage of graphic elements (photographs, drawings, graphs, etc.). In contrast, the generalized resource of virtual media communication (internet, television, radio) can be qualified as non-linear, heterogeneous, where the word a priori acts as a component of a highly structured, dynamically changing communication. The media resource in radio communication, of course, is based on the means of audio-creolization, the usage of music for optimal reporting to the recipient of the necessary information because of the absence of an image. The attraction of the original, specially created or fragments of already known compositions, updating the background knowledge about social life, culture, art etc. is very indicative in this case.

In spite of nature of media sphere, dynamic nature of its communication, tendencies of the permanent evolution of its language and functions it is very important to pay research 
attention on syncretism of the means of informing in connection with the effectiveness of the impact on the mass language consciousness, that is a predictable result of the activities of the media. That is why creolization resourse is very important and significant component for media communication that in general determines and reflects the development of means, implication and functions of modern literary languages.

\section{ЛІТЕРАТУРА}

1.Анисимова Е.Е. Лингвистика текста и межкультурная коммуникация (на основе креолизованных текстов). - M. : Академия, 2003. - 128 с.

2.Белова А.Д. Визуализация товаров в современной рекламе как составная креолизации коммуникативного пространства / А.Д. Белова // Лінгвістика XXI століття : нові дослідження i перспективи. - К. : Логос, 2012. - С. 42-50.

3.Валгина Н.С. Теория текста / Н.С. Валгина. - М. : Логос, 2003.

4.Ворошилова М.Б. Креолизованный текст : кинотекст / М.Б. Ворошилова // Политическая лингвистика. 2007. - № 2 (22). C. 106-110.

5.Громова Н.С. Креолизация текстов печатных СМИ как способ манипуляции адресатом / Наталья Сергеевна Громова // Филологические науки. Вопросы теори и практики. - Тамбов : Грамота, 2014. - № 8 (38). - Ч. 1. - С. 59-63.

6.Нежура Е.А. Новые типы креолизованных текстов в коммуникативном пространстве [Эл. ресурс] / Е.А. Нежура. - Режим доступа : http://tl-ic.kursksu.ru/pdf/012-007.pdf

7.Сорокин Ю.А. Креолизованные тексты и их коммуникативная функция / Ю.А. Сорокин, Е.Ф. Тарасов // Оптимизация речевого воздействия. - М. : Высшая школа, 1990. С. $180-186$.

8.Удод Д.А. Креолизованный текст как особый вид паралингвистически активного текста [Текст] / Д.А. Удод // Современная филология : материалы II междунар. науч. конф. (г. Уфа, январь 2013 г.). - Уфа : Лето, 2013. - С. 97-99. 


\section{REFERENCES}

1. Anisimova E.E. Linguistics of the text and intercultural communication (based on creolized texts) [Lingvistika teksta i mezhkulturnaya kommunikatsiya (na osnove kreolizovannyih tekstov)]. - M., 2003. - $128 \mathrm{~s}$.

2. Belova A.D. Visualization of goods in modern advertising as a component of the creolization of the communicative space [Vizualizatsiya tovarov $\mathrm{v}$ sovremennoy reklame kak sostavnaya kreolizatsii kommunikativnogo prostranstva] / A.D. Belova // Lingvistika XXI stolIttya : novi doslidzhennya i perspektivi. - K. : Logos, 2012. S. $42-50$.

3. Valgina N.S. The theory of the text [Teoriya teksta] / N.S. Valgina. - M. : Logos, 2003.

4. Voroshilova M.B. Creolized text: cinema text [Kreolizovannyiy tekst : kinotekst] / M.B. Voroshilova // Politicheskaya lingvistika. 2007. № 2 (22). - S. 106-110.

5. Gromova N.S. Creolization of print media texts as a way of manipulating the addressee [Kreolizatsiya tekstov pechatnyih SMI kak sposob manipulyatsii adresatom] / Natalya Sergeevna Gromova // Filologicheskie nauki. Voprosyi teori i praktiki. - Tambov : Gramota, 2014. - № 8 (38). - Ch. 1. - S. 59-63.

6. Nezhura E.A. New types of creolized texts in the communicative space [Novyie tipyi kreolizovannyih tekstov $\mathrm{v}$ kommunikativnom prostranstve] [El. resurs] / E.A. Nezhura. - Rezhim dostupa : http://tlic.kursksu.ru/pdf/012-007.pdf

7. Sorokin Yu.A. Creolized texts and their communicative function [Kreolizovannyie tekstyi i ih kommunikativnaya funktsiya] / Yu.A. Sorokin, E.F. Tarasov // Optimizatsiya rechevogo vozdeystviya. - M. : Vyisshaya shkola, 1990. - S. 180-186.

8. Udod D.A. Creolized text as a special type of paralinguistic active text [Kreolizovannyiy tekst kak osobyiy vid paralingvisticheski aktivnogo teksta] [Tekst] / D.A. Udod // Sovremennaya filologiya : materialy II mezhdunar. nauch. konf. (g. Ufa, yanvar 2013 g.). - Ufa : Leto, 2013. - S. 97-99.

$$
\begin{aligned}
& \text { Дата надходження до редакції - 25.09.2017 p. } \\
& \text { Дата затвердження редакцією - 01.11.2017 p. }
\end{aligned}
$$

